\title{
BACTERIOLOGICAL STUDIES ON HAEMOPHILUS PARAGALLINARUM IN CHICKEN IN DAKAHLIA GOVERNORATE
}

\author{
Maha A E Awad Alla", Yousef A Ahmed" and Yasmin A Abd Rabouh"
}

Diagnostic Lab .Vet. Clinic ", Department of Microbiology ${ }^{* *}$

Faculty Vet. Med. Zagazig University, Zagazig, Egypt. Diagnostic Lab in Mansoura

\begin{abstract}
One hundred \& eighty samples collected from commercial layers, broiler, breeders and native breeds farms to detect the incidence of infectious coryza in Dakahlia Governorate. 12 isolates of Haemophilus paragallinarum (HPG) were isolated, these isolates could be identified morphologically, biochemically and serologically into 8 isolates belonged to serotype $A$ and the other 4 isolates belonged to serotype C.The antibiogram sensitivity test prove $d$ that the enrofloxacin was the most effective antibiotic followed by ampicillin, ciprofloxacin, amoxicillin, and the lowest one was pencillin.
\end{abstract}

\section{INTRODUCTION}

Infectious coryza is an acute upper respiratory disease of chickens characterized by sneezing, nasal discharge, facial swelling ,lacremation, sinusitis, decrease food and water consumption and retarded growth in broilers and reduce egg production in layers flocks from 10 to $40 \%$ leading to increase number of culls particularly in multiages farms (Blackall, 1999). 
Early workers identified the causative agent of infectious coryza as Haemophilus gallinarum, an organism that reqired both $\mathrm{X}$ and $\mathrm{V}$ factors for growth, however all isolates of the organisms producing agent required only V factor and named Haemophilus paragallinurm(HPG)(Chen et al., 1996 and Bragg et al.,1997).

HPG is delicate and extremely fastidious microorganism not easy to grow in pure culture in vitro requiring specific growth condition for isolation (Chen et al.,1996 and Bragg et al.,2004). HPG is Gramnegative, non motile, bipolar bacterium, coccobacilli or short rods,1-3um in length and 0.4-0.5 um in width. The capsule may be present in a virulent strain (Hinz 1973,Sawata et al.,1981 and Richarad and Gretchen, 2004 and Garcia et al, 2004).

\section{MATERIAL AND METHODS}

\section{Materials:}

\section{Samples:}

One hundred \&eighty alive and freshly dead chickens at age of 18 to 180 days were collected from layers and broilers farms scattered allover the Dakahlia Governorate. These birds suffering from sneezing, nasal discharge, lacrimation, facial swelling and anorexia.

\section{Media:}

a- Brain heart infusion broth and agar (Blackall 1989, and Horner et al 1992).

b- Blood agar.

c- Chocolate blood agar (Koneman et al.,1998).

d- Tryptose blood agar (Rimler, 1979). 
e- MacConkey agar (Cruickshank et al.,1975).

f- Sugar media.

g- Urea, Citrate, Nitrate media .

h- Phosphate buffer salin, used for antigen preparation.

i- Nicotineamide adenine dinucleotide (NAD). (Sigma).

j- Merthiolate $0.01 \%$ were used for antigen preservation.

\section{Standared strains:}

a- HPG 0083, 0222 and Modesto strains were used for antigens preparation. These strains were kindly provided from Dr. R. Rimler College of Vet. Med. Poultry Disease Research Center, Department of Avian Medicine, University of Georgia, USA. They were stored as described by Iritani et al., (1977).

b- Staphylococcus epidermidis strain were kindly provided from Bacteriology, Mycology and Immunology Department of Faculty of Vet, Med, Zagazig University, \& was used as feeder culture to HPG \& to study the satellitism phenomena.

\section{Stains:}

a- Gram's stain. Cruickshank et al., (1975).

b- Crystal violet $0.002 \%$ for antigen staining (Iritani et al., 1977).

Embryonated chicken eggs: used for preservation \& propagation of suspected Haemophilus strains.

Antimicrobial discs: used for antibiogram sensitivity test. 


\section{Methods:}

a- Bacterilogical swabs: infraorbital sinuses and tracheal swabs were taken from the collected chickens under aseptic conditions. Then cultivated onto blood agar, tryptose agar, chocolate blood agar and brain heart infusion agar plates with the feeder culture of Staphylococcus epidermidis as a source of NAD for HPG isolation. The plates were incubated at $37 \mathrm{C}$ for $24-48 \mathrm{hr}$ in the presence of $10 \%$ $\mathrm{CO}_{2}$ (candel jar) MacConkey's agar media used for other bacterial isolation. The growing colonies were examined for their shape, size and hemolysis onto blood agar.

b- Biochemical identification: Investigated according to Cruickshank et al.,(1975)and Terezol et al.,(1993): Catalase,indole,nitrate reduction test, urease test, citrate test and sugar fermentation test were applied.

Serological identification:- Antigen preparation for the suspected colonies and standared strains according to Rimler et al., (1977).

Antisera preparation according to Page (1962).

Slide agglutination test according to Irritani et al., (1977).

Antibiogram sensitivity pattern of HPG carried out according to Rimler (1979).

\section{RESULTS AND DISCUSSION}

The results of bacteriological isolation in broiler breeders and native breeds were shown in table (1) total of 118 samples yield only 5 strains of HPG with a total incidence of $4.23 \%$,E. Coli 42 isolates in incidence of $36 \%$, Staph 50 isolates in incidence of $42.37 \%$ and Pseudomonas24 isolates in incidence of $20.39 \%$. 
Bacteriological Studies On Haemophilus Paragallinarum In ...

Table (1): Incidence of HPG in broiler breeders and native breeds chickens in Dakahlia Governorate.

\begin{tabular}{|c|c|c|c|c|c|c|c|}
\hline \multirow{2}{*}{ Locality } & \multirow{2}{*}{ Breed } & \multirow{2}{*}{ Age/day } & \multirow{2}{*}{$\begin{array}{c}\text { No.of } \\
\text { samples }\end{array}$} & \multicolumn{4}{|c|}{ Bacteriological isolation } \\
\hline & & & & HPG & E.Coli & Staph & \begin{tabular}{|l} 
Pseudomonas \\
\end{tabular} \\
\hline Belkas & Hubbard & 23 & 13 & 1 & 3 & 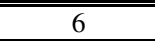 & 3 \\
\hline Talkha & $\begin{array}{l}\text { Native } \\
\text { breed }\end{array}$ & 33 & 10 & 2 & 3 & 3 & 5 \\
\hline Basandila & Hubbard & 30 & 25 & 1 & 7 & 11 & 6 \\
\hline Batra & Cubb & 40 & 24 & 1 & 8 & 12 & 3 \\
\hline Sherbin & $\begin{array}{c}\text { Native } \\
\text { breed }\end{array}$ & 30 & 8 & - & 4 & 4 & - \\
\hline El-Tawila & $\begin{array}{c}\text { Native } \\
\text { breed }\end{array}$ & 50 & 6 & - & 6 & - & - \\
\hline El-Maesara & Hubbard & 31 & 11 & - & 4 & 4 & 3 \\
\hline Dekernes & Cubb & 25 & 21 & - & 7 & 10 & 4 \\
\hline- & - & Total & 118 & $5=4.23 \%$ & $42=36 \%$ & $50=42.37 \%$ & $24=20.39 \%$ \\
\hline
\end{tabular}

The results of bacteriological isolation in layers were shown in table (2) total 62 samples yield only 7 isolates of HPG in incidence of $11.3 \%, 20$ isolates of E.Coli in incidence of 32.26\%, 25 isolates of Staph in incidence of $40.32 \%$ and 11 isolates of Pseudomonas in incidence of $17.74 \%$.

Table( 2): Incidence of HPG in layer chicken in Dakahlia Governorate.

\begin{tabular}{|c|c|c|c|c|c|c|}
\hline \multirow{2}{*}{ Locality } & \multirow{2}{*}{ Age/day } & \multirow{2}{*}{ No.of samples } & \multicolumn{4}{|c|}{ "Bacteriological isolation } \\
\hline & & & HPG & E.Coli & Staph & Pseudomonas \\
\hline Belkas & 150 & 13 & 1 & 3 & 6 & 3 \\
\hline Talkha & 140 & 11 & 2 & 4 & 4 & 1 \\
\hline Sherbin & 160 & 12 & 2 & 4 & 4 & 3 \\
\hline El-Tawila & 180 & 12 & 1 & 5 & 6 & - \\
\hline El-Maesara & 165 & 14 & 1 & 4 & 5 & 4 \\
\hline- & Total & 62 & $7=11.3 \%$ & $20=32.26 \%$ & $25=40.32 \%$ & $11=17,74 \%$ \\
\hline
\end{tabular}

Total of 180 samples revealed,12 isolates HPG, 62 E.coli,75 Staph, 35 Pseudomonas. These results were supported by Awad Alla (1989) who idntifed15 isolates of HPG (incidence 5.8\%), in addition to 33 isolates of E.coli,5 isolates of Salmonella, 9 isolates of Pseudomons, one isolate of Arizona and 14 isolates of Staph from 256 samples in Sharkia Governorate. While Zaki (1983) isolated 11 isolates of HPG from 190 examined samples at Giza Governorate with incidence 5.78\%. 
The suspected colonies were tiny dew drops like colonies up to 0.3$0.5 \mathrm{~mm}$ in diameter when incubated for 24-48 hours in the presence of $10 \% \mathrm{CO}_{2}$ and feeder culture. They were non hemolytic on blood agar and didn't grow onto MacConkey's agar media and when grow onto chocolate agar with presence of feeder culture (Staph. Epidermidis) the growth was abundant near the feeder culture. These colonies were Gram negative, coccobacilli or short rods, bipolar bacterium 1-3um in length and 0.4-0.8 um in width and non spore forming bacteria these results agree with Hinz (1973), Sawata et al (1981), Awadalla (1989), and Richard and Gretchen, 2004 and Garcia et al., (2004).

The biochemical identification revealed that Catalase, Indol, Urease and Citrate tests were negative, while Nitrate reduction was positive. Concerning to sugar fermentation maltose, mannitol were positive, galactose was negative, meanwhile lactose and sucrose showed variable results, 5 isolates showed positive reaction and 7 isolates showed negative reaction. These results supported with the results recorded by Kume et al., (1978), Narita et al., (1978), Sawata et al., (1979), Rimler (1979), Horner et al.,(1992), Terzolo et al., (1993), Blackall et al.,(1994) and (2005).

The results of serological identification by using rapid slide agglutination test showed formation of definite clumps within 1-2 minutes,8 out of these isolates belonged to serotype $\mathrm{A}(0083)$, while the other 4 isolates belonged to serotype C (Modesto). These results were similar to Awad alla (1989) who isolated15 isolates of HPG collected from different localites at Sharkia Governorate and identified 10 of them as serotype A and 5 as serovare C. While Zaki (1983) identifed 11 isolates of HPG from 190 examined samples at Giza Governorate as serovare 1. Meanwhile 
Bacteriological Studies On Haemophilus Paragallinarum In ...

Shahata et al (1988) who identified his isolates from upper Egypt as serotype 2 and Aly and Mousa (2000) who identified 18 isolates of HPG also in upper Egypt as 8 isolates belonged to serotype A, 4 isolates belonged to serotype $\mathrm{B}$ and 6 isolates belonged to serotype $\mathrm{C}$.

Regarding to the antibiogram sensitivity patteren of HPG the results were shown in table (3).

Table(3): Antibiotic sensitivity test of 12 isolates of HPG :-

\begin{tabular}{|c|c|c|c|}
\hline Chemotherapeutic & $\begin{array}{l}\text { Symbol and } \\
\text { concentration }\end{array}$ & $\begin{array}{c}\text { No.of sensitive } \\
\text { isolates }\end{array}$ & \%of activity \\
\hline Enrofloxacin & AVT(10ụg) & 11 & 91.66 \\
\hline Ampicillin & AMP(10ụg) & 9 & 75 \\
\hline Ciprofloxacin & CIP(5ụg) & 9 & 75 \\
\hline Amoxycillin & AML(10ụg) & 9 & 75 \\
\hline Norfloxacin & NOR(10ụg) & 8 & 66.66 \\
\hline Kitasamycin & KT(70ụg) & 7 & 58.33 \\
\hline Gentamycin & CN(10ụg) & 5 & 41.66 \\
\hline Sulfamethoxazole & SXT(25ụg) & 5 & 41.66 \\
\hline Erythomycin & E(15ụg) & 4 & 33.3 \\
\hline Neomycin & N(30ụg) & 3 & 25 \\
\hline Streptomycin & S(10ụg) & 3 & 25 \\
\hline Pencillin G & P(10I.U) & 2 & 16.66 \\
\hline
\end{tabular}

These results were nearly agreed with Horner et al.(1992) who recorded that enrofloxacin and ampicillin were highly potent antibiotic with an activity percentage of $100 \%$ for each while sensitivity to pencillin, neomycin and streptomycin gave variable percentage of activity. In the 
same time Peornomo et al.,(2000) indicated that 11 isolates from 18 isolates were resistant to erythromycin and streptomycin, 10 isolates were resistant to neomycin, 3 isolates were resistant to salfamethoxazole trimethoprim but only one isolate was resistant to ampicillin. On the other hand, Banani et al., (2007) proved that all isolates were sensitive to ciprofloxacin with an activity percentage of $100 \%, 3$ isolates were sensitive to enrofloxacin and streptomycin with an activity percentage of $75 \%$ for each other, 2 isolates were sensitive to ampicillin with an activity percentage of $50 \%$ and one isolate was sensitive to gentamycin and amoxicillin with an activity percentage $25 \%$ for each of them, while all isolates were completely resistant to pencillin. The obtained results were contradicted with Muhammad et al.,(1998) who indicated that gentamycin was the most effective antibiotic against HPG isolates.

Our results were supported to some extent with (Rimler, 1979; Blackall, 1988 and Zaini et al, 1991) who found that, all strains were sensitive to ampicillin, gentamycin, erythromycin, chloramphenicol, kanamycin, tetracycline. Also Soriano et al, (2001) repotted that $96.8 \%$ of the studied microorganisms were sensitive to enrofloxacin and variable susceptibility to gentamycin, amoxicillin, trimethoprim, oxitetracycline and phosphomicin. Blackall et al, (1990) suggested that resistance of $\mathrm{H}$. paragallinarum serotypes to streptomycin still predominant and this confirms our results.

We can concluded that HPG infection has economic significance in broilers as well as in layers. The most pathogenic serotypes are A and C .The most effective antibiotic are enrofloxacin followed by ampicillin, amoxicillin and ciprofloxacin. 


\section{REFERENCES}

- Aly M.M. and Mousa S.(2000): Cross protection between Haemophilus paragallinarum strains and evaluation of infectious coryza vaccines . Assiut Vet. Med. J .,43:339-353.

- Awad Alla M.E.(1989):Experimental studies on infectious coryza .MVSc. Thesis ,Fac. Vet. Med,Zag.Univ.

- Banani M., pourbakhsh S.A., Khaki P., Goodarzi H.,Moazeni-Jula G. and Ghodsian N.(2007): Isolation, identification and antibiotic sensitivity of Haemophilus paragallinarum isolates from commercial flcks affected by infectious coryza in Southwest Asia .Iran Pajouhesh va Sazandegi. Section: Agriculter Pajouhesh and Sazandeg, 73: 128135.

- Blackall, P.J. (1988): Antimicrobial drug resistance and the occurrence of plasmids in Haemphilus paragallinarum. Avian Dis. 32, (4): 742-747.

- Blackall P.J.(1989):The avian Haemophili. Clin. Microbiol. Rev., 2: 270-277.

- Blackall, P. J.; L. E. Eaves; and G. Aus (1990): Serotyping of Haemophilus paragallinarum by the Page scheme: comparison of the use of agglutination

- Blackall P.J., Silva E.N., Yamaguchi Y. and Irritani Y. (1994): Characterization of isolates of avian haemophilli from Brazil. Avian Dis., 38: 269-274.

- Blackall P.,J(1999): Infectious coryza : over view of the disease and new diagnosis options. Clin.Microbiol.Rev.,4: 627-632. 
- Blackall P.J. Christensen H., Beckenham T., Blackall L.L. and Bisgoard M.(2005): Recassification of, Haemophilus paragallinarum, Pasterulla gallinarum, Pasteurella avium and Pasteurella volantium as Avibacterium gallinarum gen. Nov., Avibactrium avium Comb. Nov. and Avibacterium Volantium Comb. nov. Int. J. Syst. Evol. Microbiology, 1: 353- 362.

- Bragg R.R., Coetzee L. and Verschoor J.A.(1997): Effect of growth conditions and incubation times on the expression of antigen of Haemophilus Paragallinarum which are detected by monoclonal antibodies . Onderstepoort J. Vet. Res., 64 (1):57-63.

- Bragg R.R., Jansen van Rensburg P., Van Heerden E. and Albertyn J. (2004): The testing and modification of a commercially available transport medium for transportion of pure culture of Haemophilus Paragallinarum for serotyping . Onderstepoort J. Vet. Res., 71(2):93-98.

- Chen X., Miflin J.K., Zhang P. and Blackall P.J.(1996): Development and application of DNA probes and PCR tests for Haemophilus Paragallinarum .Avian Dis., 40: 398-407.

- Cruickshank,R., Duguid, J.P, Marmian,B.P. and Swain, R. H. A. (1975): Medical Microbiology. The practice of Medical Microbiology. 12th Ed. Vol. II, Churchill, Livingston, Edinburgh, London and New York.

- Garcia A.J., Angulo E., Blackall P.J. and Ortiz A.M.(2004): The presence of nicotine amide dinucleotid independent Haemophilus Paragallinarum in Mexico. Avian Dis., 48(2): 425-429

- Hinz K.H.(1973): Beitrag zur differenzierung von. Haemophilus stamen aus Huhnern.1.Mitteilung : Kulturelle and biochemische untersuchngen .Avian Pathology,2:211-229. 
- Iritani Y, Sugimori G and Katgiri K (1977): Serological response to Hemophilus paragallinarum in artificially infected and vaccinated chickens .Avain Dis.21:1-8

- Horner R.F., Bishop G.C. and Colleen H.(1992): An upper respiratory disease of commercial chickens resembling infectious coryza, but caused by a V-factor independent bacterium. Avian Pathology, 21: 421-463.

- KOneman E.W., Allan S.D.,Janda W.M.,Schreckanberger P.C. and Winn W.C.(1998): Color Atlas and Textbook of Diagnostic Microbiology (fifth edition).Lippincott.

- Kume, K.; Sawata A. and Nakai Y (1978):Haemophilus infection. Characterization of Haemophilus paragallinarum isolated from chickens affected with coryza.Jap. J.Vet.Sci.,40: 65-73.

- Narita N., Hipolito O. and Bottion J.A.(1978): Studies on infectious coryza in chickens. 1 .The biochemical and serological characteristic of 17 Haemophilus strains isolated in Brazil. Proc. $16^{\text {th }}$ World's Poult. Conger., 685-692.

- Page,L.A.(1962): Haemophilus infections in chickens. 1. Characteristics of 12 Haemophilus isolates recovered from diseased chickens. Am. J. Vet. Res. 23:85-95.

- Poernomo S., Sutarma S., Rafiee M. and Blackall P.J. (2000). Characterization of isolates of Haemophius paragallinarum from Indonesia .Aust. Vet. J., 78(11):759-762.

- Richard J. and K. Gretchen (2004): Avian bacterial, mycoplasma and Chlamydia diseases. 326 Zoological Medicine tufts open course ware (Tufts University). 
- Rimiler, R.B. (1979): Studies of the pathogenic avian haemophili. Avian Dis. 23 (4): 1006-1018.

- Rimiler, R.B., Shotts E.B., Brown J. and Davis R.B.(1977): The effect of sodium chloride and NADH on the growth of six strains of haemophilus species pathogenic to chickens. J.Gen. Micro.,98:349354.

- Sawata A., Kume K. and Nakase Y.(1979): Antigenic structure and relationship between serotype 1 and 2 of Haemophius paragallinarum. Am. J. Vet. Res., 40: 1450-1453.

- Sawata A., Kume K. and Nakase Y.(1981): Biologic and serologic relationship between Page's Sawata 's serotype of of Haemophius paragallinarum. Am.J.Vet.Res., 41: 1901-1904.

- Sahata M., Soliman A., Ibrahim A. and Mousa S. (1988):Studies on infectious coryza and associating bacterial agents in upper Egypt . 1. Epidemiological studies . Proc. 3 rd Sci. Cong., Fac. Vet. Med., Assiut Univ., Nov.20-22.

- Soriano V.E.; Blackall P.J., Dabo S.M., Tellez G., Garcia-Delgado G.A. and Fernández R.P.(2001): Serotyping of Haemphilus paragallinarum isolated identificated from Mexico by the Kume haemagglutinin scheme. Avian Dis., 45 (3): 680-683

- Terzolo, H. R.; F. A. Paolicchi; V. E. Sandoval; P. J. Blackall; T. Yamaguchi; and Y. Iritani (1993): Characterization of isolates of Haemophilus paragallinarum from Argentina. Avian Dis. 37:310-314

- Zaki M.M.(1983): Studies on infectious coryza in poultry in Egypt. M.V.Sc, Thesis (Poultry Diseases) Fac. Vet. Med., Cairo University.

- Zaini M.Z.; A.T. Siti-zaleha and L.J. Tan (1991): Characterization of Haemphilus paragallinarum isolated in Malaysia. J. Vet. Malaysia. 3(1): 25-30. 


\section{دراسات بكتريولوجية على ميكروب الهيموفلس باراجالينرم فى الدجاج بمحافظة الدقهلية}

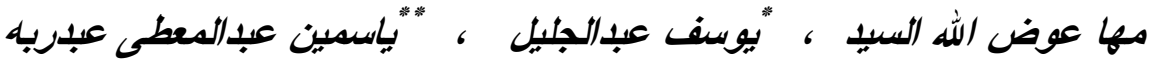

مستثفى كلية الطب البيطرى ( دواجن) - جامعة الزقازيق

"قسم الميكروبيولوجى - كلية الطب البيطرى - جامعة الزقازيق

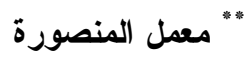

قد تم تجميع 180 عينه من دجاج مختلف السلالة من مزارع حكومية وأهليه منتشرة في أماكن مختلفة في محافظه الدقهليه وتم إجراء الفحص لبكتريولوجي والاختبارات البيوكيميائيه و السيرولوجيه وكذلك تم عمل اختبار ات الحساسية لهذه العترات ضد أنو اع مختلفة من المضادات الحيويه وكانت النتائج كالاتي تم عزل 12 عتره من عتر ات الهيموفلس بار اجالينيرم وقد نم تصنيفها علي اساس الفحص الدورفولوجي وقابليتها لصبغه الجرام و الاختبار ات البيوكيميائيه والسيرولوجيه إلى 8 عترات تتنمي إلى العتره وأربع عترات تتنمي إلى العتره وبإجر اء اختبار الحساسية تبين أن انروفلوكساسين هو اكثر المضادات الحيويه فاعليه 91.66 \% يليه الامبسلين و السبروفلوكساسين بنسبه 75\% لكل منهم واثبت الاختبار أن اقل المضادات الحيوية تأثثر ا هم الاستربتومايسين و النيومايسين و الأموكسيسلين بنسبه 25\% و أخيراً البنسلين بنسبه 17\%. 